\title{
The role of infrastructure sustainability and success of construction projects on owner benefits
}

\author{
Thanachon Krajangsri ${ }^{1, *}$ and Jakrapong Pongpeng ${ }^{1}$ \\ ${ }^{1}$ Civil Engineering Department, Faculty of Engineering, King Mongkut’s Institute of Technology Ladkrabang, Bangkok, Thailand
}

\begin{abstract}
The infrastructure sustainability and success of construction projects likely influence owner benefits. However, these influences have rarely been examined. Thus, the research aimed to examine such influences and intervening behavior of the success of construction projects between the sustainability of infrastructure and owner benefits using structural equation modeling (SEM). The study finds that there are a direct influence of the sustainability of infrastructure on owner benefits (regression weight: 0.63 ) and an indirect direct influence of that (regression weight: 0.22 ) through the intervening role of the success of construction projects. The findings ensure that implementation of infrastructure sustainability projects can enhance the success of construction projects and owner benefits.
\end{abstract}

\section{Introduction}

A successful construction project yields several benefits to an owner. The benefits should cover various terms to maintain an owner organization in business, society and community. In terms of economics, financial returns of the project should satisfy the owner company by supporting its financial viability. Therefore, accomplishing success in construction projects is crucial to the owner benefits [1]. Modern infrastructure projects need to concern about sustainable issues of sociality, environment and economics during their life cycle because achieving infrastructure sustainability can increase the owner competitiveness, reputation and business opportunities while conserving environmental characteristics of the projects [2].

Previous studies demonstrate possible relationships between sustainability of infrastructure and success of construction projects and owner benefits. However, these relationships have seldom been proved. This study was aimed to develop a model to examine (1) the influence between the infrastructure sustainability and owner benefits and (2) the intervening role of success of construction projects between the sustainability of infrastructure and owner benefits. The results from this study provide apparent understanding of the influence of the sustainability of infrastructure and success of construction projects on owner benefits.

\section{Literature review}

The literature on the three elements of owner benefits, sustainability of infrastructure and success of construction projects were reviewed to form research hypotheses and to develop conceptual models.

\subsection{Owner benefits}

To determine the owner benefits, the Triple Bottom Line concept of social, environment and economic aspects, was used as a framework for categorizing the benefits.

\subsubsection{Social benefits}

Institute for Infrastructure Sustainability [3] proposed the social benefits as follows: improved quality of life, encouragement of community growth and development, development of community workforce skills, increased public health, safety and well-being, increased collaboration and involvement of stakeholders, higher stakeholders satisfaction, and preservation of cultural heritage. Guarnieri [4] suggested social benefits as follows: improved community quality of life and increased project users health and comfort. Based on previous studies, the social benefits of sustainability in this study are described by: improved project owner's reputation, improved country's reputation, improved project users' quality of life, and improved community acceptance.

\subsubsection{Environmental benefits}

ISI [3] suggested the following environmental benefits: reduced energy and water consumption, reduced risks from natural disasters, preservation of ecological systems, reduced air pollutants and harmful emissions, less use of natural resources and impacts on ecological systems, and increased resilience to climate change and natural disasters. Olsen and Fenhann [5] identified various sustainable environmental benefits as follows: improved air quality, reduced harmful emissions, improved water quality, and protection of natural

\footnotetext{
* Corresponding author: thanachon $(a$, hotmail.com
} 
resources. Based on previous studies, the environmental benefits of sustainability in this study are indicated by: improved project resilience to natural disasters, reduced environmental impacts from the project, protection of natural resources and ecological systems, and provision of education opportunities on sustainability.

\subsubsection{Economic benefits}

Dobson et al. [6] suggested the following economic benefits: reduced operation costs, reduced utilities costs, and reduced maintenance costs. Lee et al. [7] found economic benefits as follows: reduced energy costs, reduced water costs, economic growth improvement, increased income, and lower environmental impact costs. ISI [3] proposed the following economic benefits: reduced energy costs, reduced water costs, reduced maintenance costs, and reduced construction material costs. Based on previous studies, the economic benefits of sustainability in this study are determined by: reduced energy costs, reduced water costs, reduced operation and maintenance costs, and improved access to budget.

\subsection{Sustainability of infrastructure}

The infrastructure sustainability assessment systems and related studies are reviewed in this section to determine criteria and sub-criteria to obtain and evaluate infrastructure sustainability. CEEQUAL suggested 9 criteria in the latest version 5, including project strategy, project management, people and communities, land use and landscape, the historic environment, ecology and biodiversity, the water environment, physical resourcesuse and management, and transport [8]. Envision proposed 5 major criteria for assessment including quality of life, leadership, resource allocation, natural world, and climate and risk [3]. Assessment criteria for GreenLITES were proposed as follows: sustainable sites, water quality, materials and resources, energy and atmosphere, and innovation [9]. Greenroads used 7 assessment criteria: project requirements (mandatory), environment and water, access and equity, construction activities, materials and resources, pavement technologies and custom credits [10].

The sustainability of infrastructure for this study was described by 9 criteria: project management, location, energy, water, materials and resources, waste management, transportation, environmental impacts on surrounding areas, and community as found in the study of Krajangsri and Pongpeng [11].

\subsection{Success of construction projects}

A construction project is considered successful if it meets traditional indicators of time, cost and quality [12]. Alzahrani and Emsley [13] identified nine categories of success indicators: health, safety and quality, past performance, environment, management and technical aspects, resources, organization, experience, size/type of previous projects, and finance. Tabish and Jha [14] suggested 24 success indicators which were grouped into 5 categories comprising time, cost, quality, safety and no-dispute. Enshassi et al. [15] found ten success indicators as follows: cost, time, quality, productivity, client satisfaction, community acceptance, society, health and safety innovation, and environment. The success of construction projects for this research was described by 6 indicators: time, cost, quality, safety, client and community satisfaction, and environment as found in the study undertaken by Krajangsri and Pongpeng [11].

\subsection{Hypothesis of the research}

Improving infrastructure projects to be more sustainable have become an important agenda for the owner because ignoring social and environmental issues can negatively affect the owner reputation and long-term benefits. Then, implementing infrastructure sustainability assessment of projects can minimize these negative effects while enhancing the owner business opportunities, competitiveness and status [3]. Although previous studies displayed a possible relationship between sustainability of infrastructure and owner benefits, the relationship has never been examined. Therefore, the hypothesis was formed:

H1: Sustainability of infrastructure directly influences owner benefits.

Krajangsri and Pongpeng [11] found that the sustainability of infrastructure directly influenced the success of construction projects. Based on these studies, the hypothesis was established:

$\mathrm{H} 2$ : Sustainability of infrastructure directly influences success of construction projects.

Herzig and Schaltegger [16] found that adopting sustainable success criteria can improve public acceptance, increase reputation, enhance competitiveness, increase transparency, motivate employee, act as a benchmark for a company, and determine economic benefits from sustainable activities. Previous studies show that there may be a relationship between success measures of construction project and owner benefits. The hypothesis was formulated to test the relationship:

H3: Success of construction projects directly influences owner benefits.

Several studies suggested that successful sustainable construction creates both direct and indirect benefits to the owners. Direct benefits are minimized environmental impacts, lower or equal initial costs, reduced energy and water costs; while, indirect benefits are better health and safety of project users, improved comfort and satisfaction of project users, increased productivity, longer project lifespan, and improved project image [1718]. From these studies, there may be an indirect relationship between sustainability of infrastructure and owner benefits through an intervening role of success of 
construction projects. The hypothesis was set to test this role:

H4: There is an indirect relationship between sustainability of infrastructure and owner benefits through an intervening role of success of construction projects.

\section{Structural equation modelling and conceptual SEM model}

Structural equation modeling (SEM) is a multivariate statistical tool combining confirmatory factor analysis, multiple regression analysis and path analysis to test a hypothesis on the (either direct and indirect or both) relationship of observed and latent (unobserved) variables. Observed variables carry the data that a researcher can directly measure. Whereas, latent variables carry the data that a researcher is interested but cannot directly measure. Variables in SEM can also be divided into exogenous and endogenous variables, depending on the direction of influence. Exogenous variables are independent variables that influence other variables. Endogenous are dependent variables that are influenced by other variables. In SEM, both exogenous and endogenous variables, which can be observed or latent, are considered [19].

\section{Questionnaire for data collection}

In order to test the hypotheses, 500 questionnaires were handed to samples in public and private sectors in Thai construction industry. 371 completed questionnaires were returned, translating to a response rate of $74 \%$, which is considered as excellent [20]. The samples were asked to rate the significance level of each criterion/indicator according to a Likert scale of 1 to 5 .

\section{Results and discussion}

First, the measurement models were confirmed that they fit the sample data from the following goodness-of-fit criteria: p-value of 0.236 (more than the accpeted value of 0.05$)$, relative chi-square $\left(x^{2} / \mathrm{df}\right)$ of 1.029 , goodnessof-fit index (GFI) of 0.891 (more than the accepted value of 0.09), and root mean square error of approximation (RMSEA) of 0.009 (more thant the minimum value of 0 ) [21]. To validate the conceptual SEM model, hypotheses $\mathrm{H} 1, \mathrm{H} 2$ and $\mathrm{H} 3$ were tested to examine direct influences among the latent variables as shown in Fig. 2. H1 tested that sustainability of infrastructure directly influences owner benefits. H1 was accepted because the p-value was less than 0.05 with a regression weight of 0.63 . H2 and $\mathrm{H} 3$ tested that sustainability of infrastructure directly influences the success of construction projects and that the success of construction projects directly influences owner benefits.

$\mathrm{H} 2$ and $\mathrm{H} 3$ were accepted because the p-values were less than 0.05 with regression weights of 0.84 and 0.26 , respectively. Since H2 and H3 were accepted, this implied an existence of the indirect influence between sustainability of infrastructure on owner benefits via the success of construction projects. The indirect influence was calculated by multiplying a regression weight of 0.84 (derived from the path of sustainability of infrastructure to the success of construction projects) by that of 0.26 (derived from the path of the success of construction projects to owner benefits), resulting in a regression weight of 0.22 . Then, the regression weight (representing the indirect influence on the path of sustainability of infrastructure to the success of construction projects to owner benefits) of 0.22 was added to the regression weight (representing the direct influence on the path of sustainability of infrastructure to owner benefit) of 0.63 , producing the total regression weight (representing the total influence) of 0.85 . Obviously, the total influence was more than the direct influence; thus, $\mathrm{H} 4$ was accepted. The influences of sustainability of infrastructure on the success of construction projects and on the owner benefits are shown in Fig. 1. (Details of observed variables describing latent variables of criteria can be seen in [11])

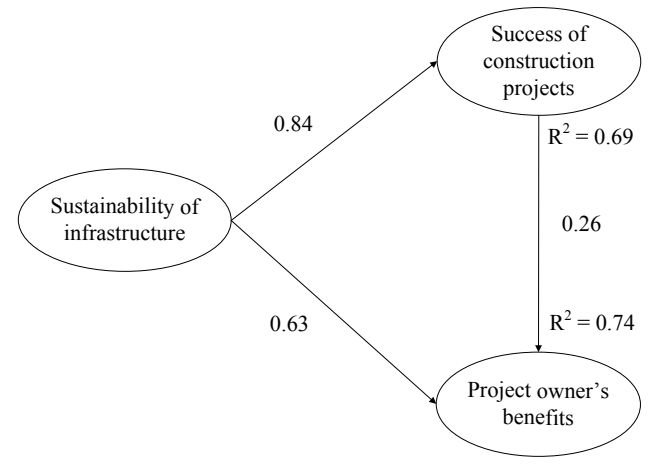

\section{Fig. 1. Final SEM model}

The results demonstrate that sustainability of infrastructure has higher direct influence on owner benefits (regression weight: 0.63) than that of the success of construction projects on owner benefits (regression weight: 0.26 ). This reinforces the belief that implementation of the infrastructure sustainability results in not only higher level of success of construction projects but also more owner benefits in terms of environment, economics and society. The owner, therefore, should incorporate sustainability concepts, such as preparation of flood risk assessment, waste management plan, and enhancement of community accessibility into the design of infrastructure. When the success of construction projects plays an intervening role between sustainability of infrastructure and owner benefits, the total influence was increased from 0.63 to 0.85 (a combination of direct influence (0.63) and indirect influence $(0.22)$ ). This demonstrates that successful construction projects, as an intervening variable, can generate long-term indirect benefits to the owner such as increased comfort and safety of project users, and improved reputation of the owner. 


\section{Conclusions}

Infrastructure sustainability is one of key components in sustainable development strategy, which holistically consider social, environmental and economic dimensions. Although previous studies have suggested that sustainability of infrastructure enhances project success but the studies to examine the influence of the infrastructure sustainability on owner benefits were limited. Additionally, the intervening role of the success of construction projects between the sustainability of infrastructure and owner benefits has not been investigated. Therefore, the research was aimed to examine (1) the influence of sustainability of infrastructure on owner benefits and (2) whether the success of construction projects intervene between the sustainability of infrastructure and owner benefits. Then, hypotheses were formulated to test the influence and the intervening role. Questionnaires were used to collect the data from government and public agencies. After that, the data were used to validate the conceptual SEM model.

The SEM analysis results showed that all the hypotheses were accepted, meaning that the sustainability of infrastructure directly influenced the owner benefits. In addition, the total influence was significantly increased when the success of construction intervened between the sustainability of infrastructure and owner benefits, emphasizing its intervening behavior. The study originally contributes to examine the relationships between the infrastructure sustainability, success of construction projects and owner benefits. However, the relationships may alter depending on types and geographical locations of the infrastructure projects. Thus, further studies to examine the relationships based on the alternation are recommended.

\section{References}

1. Pankaj, A. J. J. and Bhangale, P., To Study Critical Factors Necessary for a Successful Construction Project, IJITEE , 2, 5 (2013)

2. Levitt, R., CEM research for the next 50 years: Maximizing economic, environmental, and societal value of the built environment, J. Constr. Eng. M, ASCE 133, 9 (2007)

3. ISI, Envision: A Rating System for Infrastructure sustainability v.2.0. Institute for Infrastructure Sustainability. Washington, DC, USA (2012)

4. Guarnieri, T.J., The real cost of sustainable development, AACE International Transactions (2008)

5. Olsen, K.H. and Fenhann, J., Sustainable development benefits of clean development mechanism projects. A new methodology for sustainability assessment based on text analysis of the project design documents submitted for validation, Energ. Policy. 36 (2008)
6. Dobson, D.W, Sourani, A., Sertyeilisik, B,.., and Tunstall, A., Sustainable construction: Analysis of its costs and benefits, Am. J. Civil. Eng., 1, 2 (2013)

7. Lee, K.H., Ahn, Y.H., Jeon, M., and Suh, M.J., Organizational strategies to support sustainability in the construction company, In the World SB14 Barcelona, October 28-30 ${ }^{\text {th }}, 2014$ (2014).

8. CEEQUAL, Assessment Manual for Projects in the $U K \&$ Ireland v.4.1, http://www.ceequal.com (2010)

9. NYSDOT, New York State Department of Transportation http://www.dot.ny.gov/programs/greenlites

10. Greenroads, Greenroads Abridged Manual v1.5, http://www.greenroads.org/366/download-the$\underline{\text { manual.html (2011) }}$

11. Krajangsri, T., Pongpeng, J.,. Effect of Sustainable Infrastructure Assessments on Construction Project Success Using Structural Equation Modeling. J. Manage. Eng. 33, 3 (2017)

12. Atkinson, R., Project management: cost, time and quality, two best guesses and a phenomenon, its time to accept other success criteria, Int. J. Proj. Manag. 17 (1999)

13. Alzahrani, J. and Emsley, M. W., The impacts of contractors' attributes on success of construction projects: A post construction evaluation, Int. J. Proj. Manag. 31 (2013)

14. Tabish, S. Z. S. and Jha, K. N., "Important Factors for Success of Public Construction Projects." In the $2^{\text {nd }}$ International Conference on Construction and Project Management, IPEDR, 15 IACSIT Press, Singapore, (2011)

15. Enshassi, A., Mohamed, S., and Abushaban, S.,. Factors affecting the performance of construction projects in the Gaza Strip, J. Civ. Eng. Manag. 15, 3 (2009)

16. Herzig, C. and Schaltegger, S., Corporate Sustainability Reporting. An Overview Sustain. Account. Rep. Dordrecht, Springer (2006)

17. Bordass, G., The Economics Benefits of Sustainable Design (2003)

http://www1.eere.energy.gov.femp/pdfs/buscase_sec tion2.pdf

18. Brightman, H. a. M., J., The Social Benefits of Sustainable Design. (2001)

http://www1.eere.energy.gov?femp/pdfs/buscase se ction3.pdf

19. Cho, K. M., Hong, T. H., and Hyun, C. T, Effect of project characteristics on project performance in construction projects based on structural equation model, Expert Syst. Appl. 36 (2009)

20. Babbie, E. R., The practice of social research. Belmont, CA: Wadsworth (1989)

21. Marsh, H. W., Balla, J. R., and McDonald, R. P. "Goodness-of-fit indices in confirmatory factor analysis: the effect of sample size." Psychol. Bull., 103, 3 (1988) 